\title{
COLOLEJEUNEA MANILALIA \\ (LEJEUNEACEAE, MARCHANTIOPHYTA), A NEW SPECIES FROM THE WESTERN GHATS OF INDIA
}

\author{
C. N. Manju*, V. K. Chandini and K. P. Rajesh \\ Department of Botany, Zamorin's Guruvayurappan College \\ (affiliated to the University of Calicut), GA College PO., Kozhikode, Kerala-673014, India; \\ *E-mail: manjucali@gmail.com
}

(Received 1 November, 2016; Accepted 15 December, 2016)

Cololejeunea manilalia sp. nov., an epiphyllous leafy liverwort, collected from the high altitude, tropical wet evergreen shola (cloud forest) of the New Amarambalam Reserved Forest in the Western Ghats of India is described and illustrated.

Key words: Cololejeunea manilalia, India, Kerala, leafy liverwort, Lejeuneaceae, New Amarambalam, Western Ghats

\section{INTRODUCTION}

The New Amarambalam Reserved Forest, located in the Nilgiri Biosphere Reserve with an area of more than $260 \mathrm{~km}^{2}$, is one of the most notable areas in the Western Ghats of Northern Kerala for its unique assemblage of floristical elements. It lies in contiguous with the Mukuruthi National Park of the Tamil Nadu. The floristical diversity of the area has been explored by Sharma et al. (2002), and reported the occurrence of 305 tree species with 212 genera and 73 families. Later Jayakumar (2005) and Jayakumar and Nair (2005) reported 1,135 taxa of angiosperms with 644 genera and 136 families. All the earlier studies in this area had been concentrated on its angiosperm diversity only. A new moss, Symphysodontella madhusoodananii, was reported from the area by Manju and Rajesh (2012).

Cololejeunea is a large hepatic genus in tropical and sub tropical regions, and most of them prefer epiphyllous habitat. The members are characterised by the absence of underleaves. About 345 valid species of Cololejeunea are reported from the world (Asthana and Srivastava 2003, Pócs 1996, Pócs et al. 
2014, Singh and Pócs 2016, Singh and Nath 2007, www.discoverlife.org/20/q). In India it is represented by 42 species (Asthana and Srivastava 2003, Day and Singh 2012, Day et al. 2010, Singh and Nath 2007).

In the course of our recent studies on the family Lejeuneaceae of the Western Ghats, we found a new taxa of the genus Cololejeunea from the Shola forests (Southern Montane Wet Temperate Forests) of the New Amarambalam Reserved Forest in the Malappuram District of Kerala state. It is characterised by distantly arranged reniform leaves, absence of prominent vitta and intermediate nodular thickenings of the median cells, and is described here as Cololejeunea manilalia sp. nov.

Key to the related species of Cololejeunea manilalia

1a Leaves imbricate, stylus present 2

1b Leaves distantly arranged, stylus absent 3

2a Vitta present, 3-4-celled, uniseriate; gynoecium on short lateral branches C. indica

$2 \mathrm{~b}$ Vitta absent; gynoecium on terminal branches C. spinosa

3a Leaf ovate-oblong, apex subacute, leaf lobule inflated, bilobed, first tooth small, single-celled, second tooth also single-celled; absence of interme$\begin{array}{ll}\text { diate nodular thickenings in median cells } & \text { C. nilgiriensis }\end{array}$

3b Leaves reniform, apex obtuse, leaf lobule slightly inflated, first tooth long and straight, usually 2-celled, second tooth small, single-celled; presence of intermediate nodular thickenings in median cells Cololejeunea manilalia

\section{Cololejeunea manilalia Manju, Chandini et Rajesh, spec. nova} (Figs 1-2)

Type: INDIA, Kerala, Malappuram district, Nilambur, New Amarambalam Reserved Forest (bordering Mukurti National Park of Tamil Nadu), plants epiphyllous, seen in association with Cololejeunea spinosa and Frullania sp., 1,200 m alt., coll.: Rajesh, K. P. (111812a) 06.02.2010, (holotype: ZGC!; isotypes: BM!, CAL!, CALI!, ZGC!).

Diagnosis: Plants light yellowish green, yellowish brown in herbarium, main stem 3-6 mm long, about $0.04 \mathrm{~mm}$ in diameter, with leaves $0.4-0.45 \mathrm{~mm}$ wide; rhizoids few, hyaline, in tufts 8-9.7 $\mu \mathrm{m}$ wide; branching irregular, cross section of stem $42.3-57.2 \mu \mathrm{m}$ across the diameter, with a circle of 5 cortical cells, $13.3-22 \times 11.17-16.52 \mu \mathrm{m}$ and one medullary cell, $12.75 \times 9.46 \mu \mathrm{m}$, cells thin walled, trigones absent; leaves reniform in shape, distant, dorsal lobe mar- 
gin convex, $0.18-0.23 \mathrm{~mm}$ long, $0.09-0.14 \mathrm{~mm}$ wide, margin densely spinose throughout, apex obtuse, ventral margin incurved at middle, marginal cells pentagonal in shape, 10-14.9 $\mu \mathrm{m}$ long, median cells 12.2-16.41 × 9.9-10.7 $\mu \mathrm{m}$, pentagonal to hexagonal in shape, intermediate nodular thickening present, basal cells elongate, $22.2-28.6 \mu \mathrm{m}$, cells arranged at the base of leaf resembles the ocelli in size, one single dorsal papilla on each cell, leaf lobule 2/5-1/2 length of the leaf lobe, ovate, slightly inflated along the keel, stylus absent,
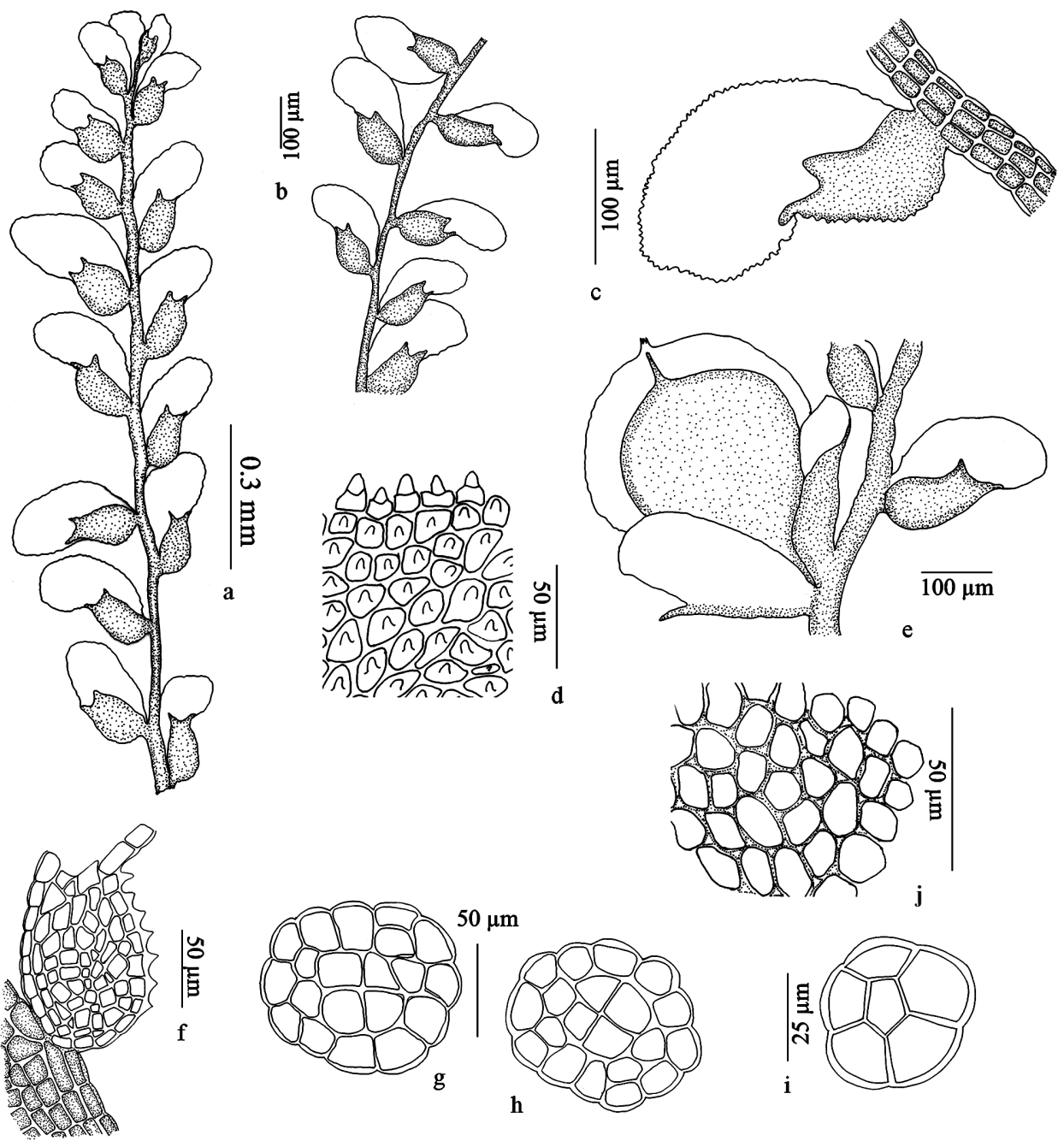

Fig. 1. Cololejeunea manilaliana. $\mathrm{a}-\mathrm{b}=$ habit ventral view; $\mathrm{c}=$ leaf lobe with lobule; $\mathrm{d}=$ leaf marginal cells; $\mathrm{e}=$ gynoecial branch; $\mathrm{f}=$ cells of leaf lobule; $\mathrm{g}-\mathrm{h}=$ gemmae; $\mathrm{i}$ = cross section of stem; $\mathrm{j}=$ leaf middle cells 


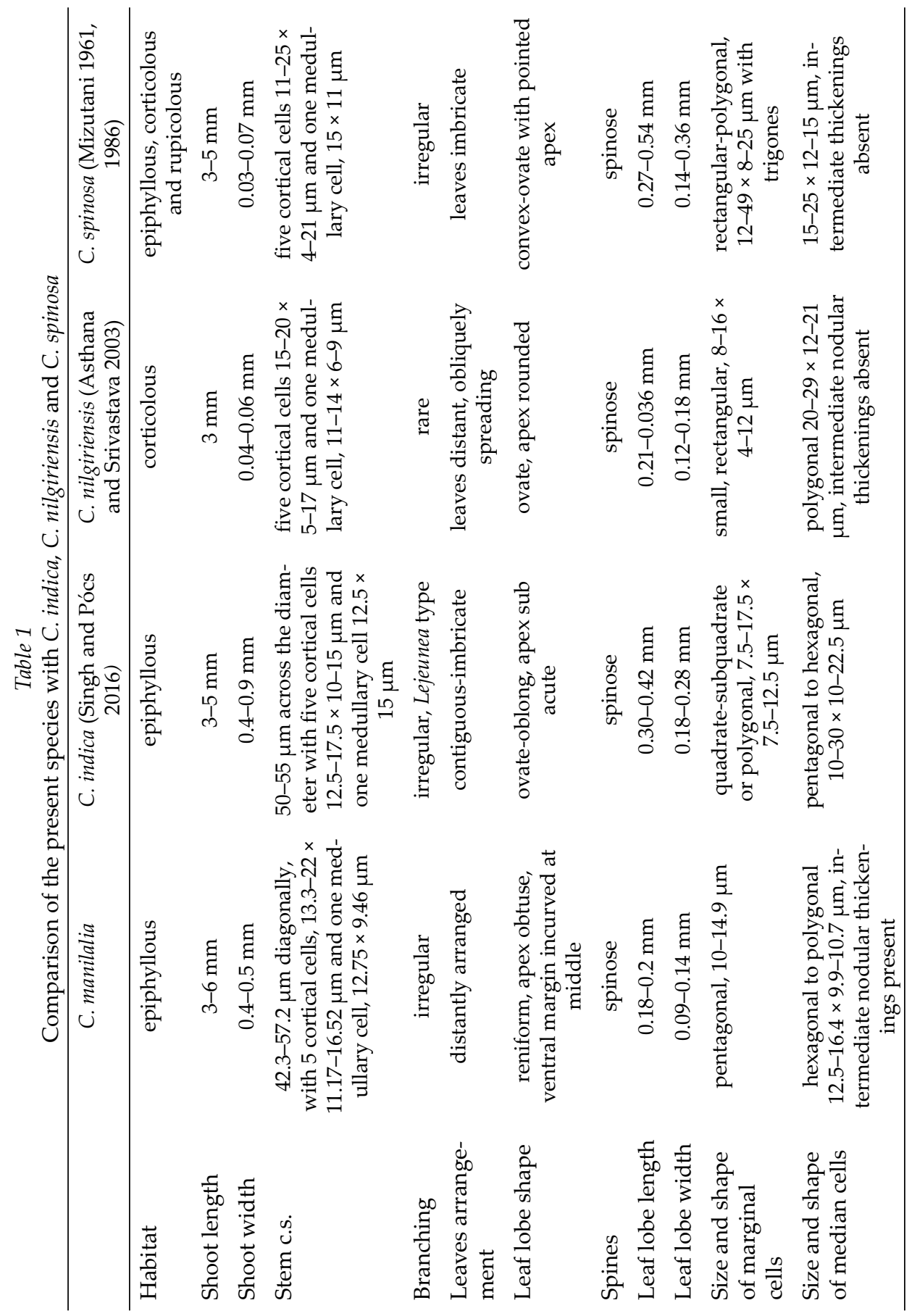




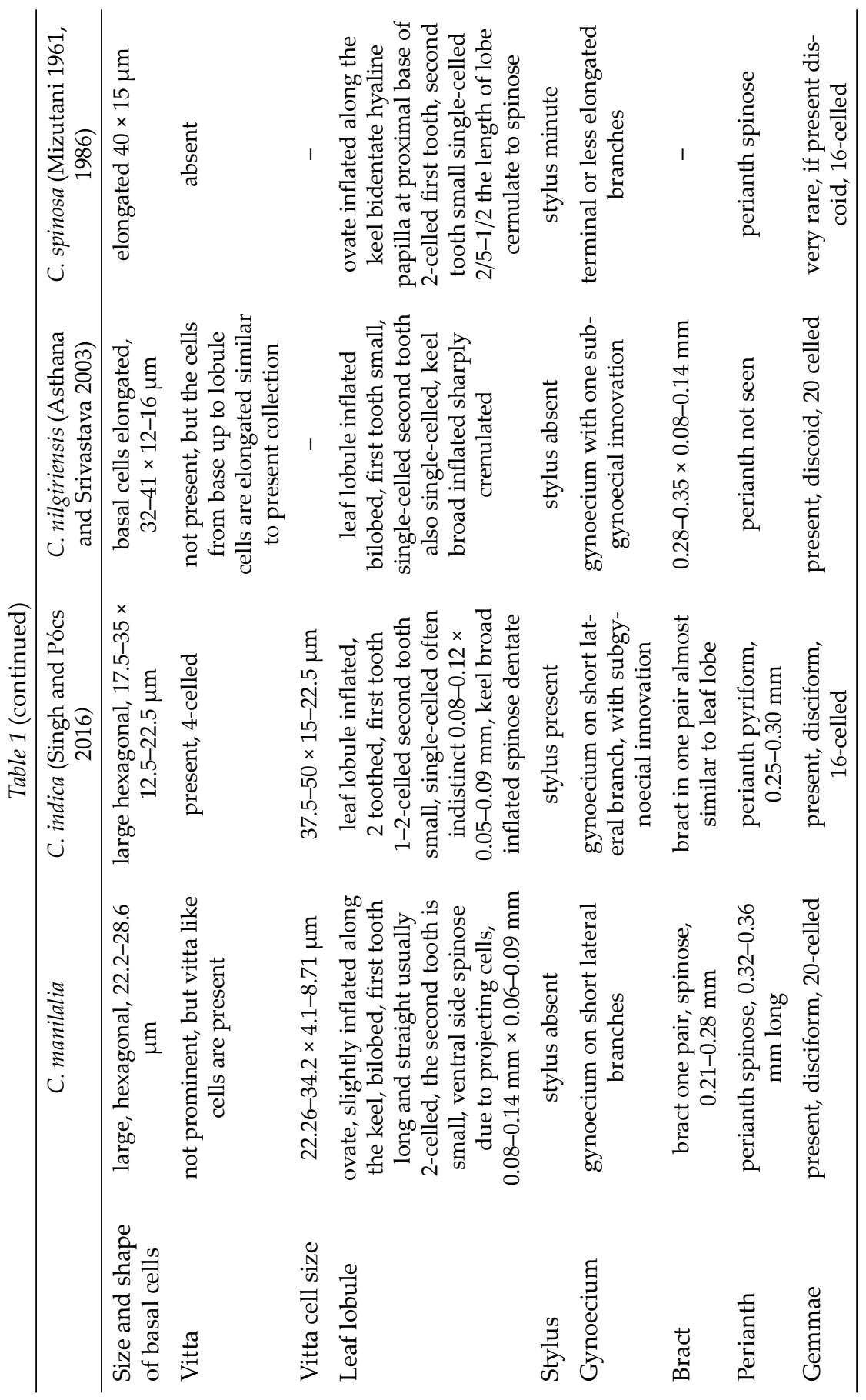


bilobed, first tooth long and straight usually 2-celled, second tooth small, ventral side spinose due to projecting cells; keel arched, densely spinose; gynoecium on short lateral branches, bract one pair, spinose, compared to normal leaf lobe bract linear, $0.21-0.28 \mathrm{~mm}$, perianth spinose, $0.32-0.36 \mathrm{~mm}$ long, androecium not observed; discoid shape, with 20 cells (Figs 1-2).

Ecology: Plants epiphyllous, seen in association with C. spinosa and Frullania sp.
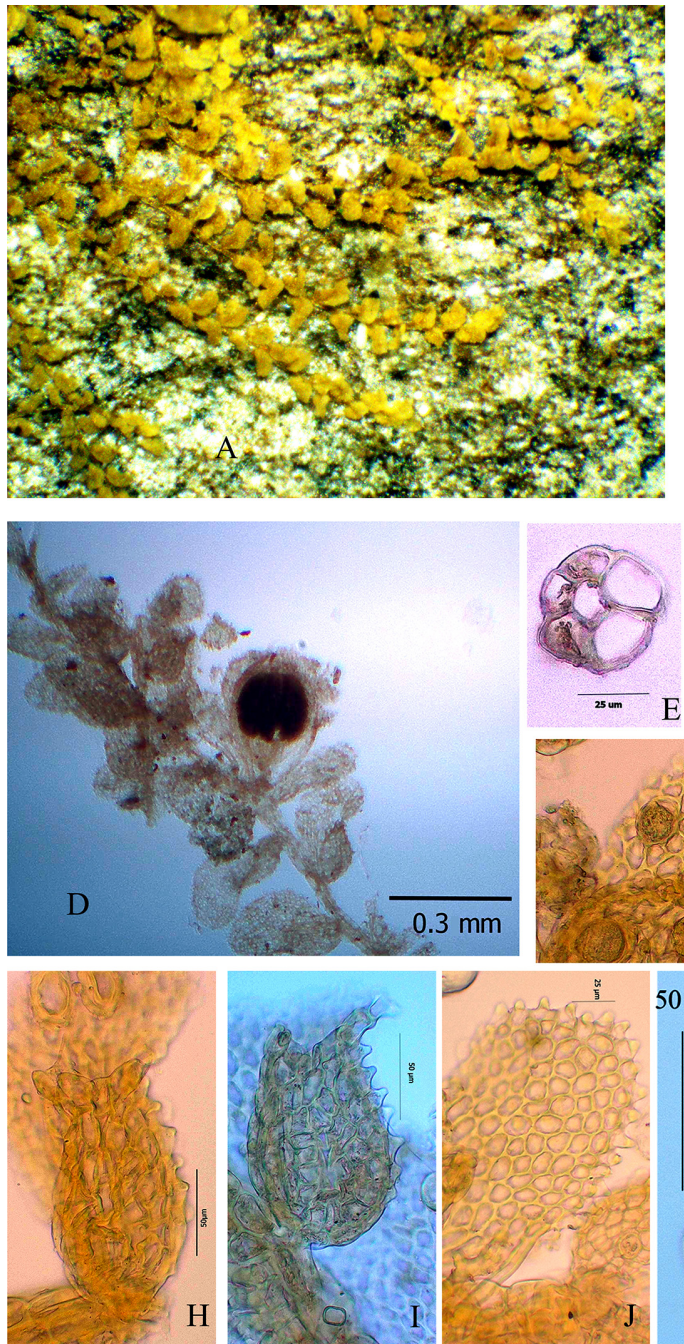
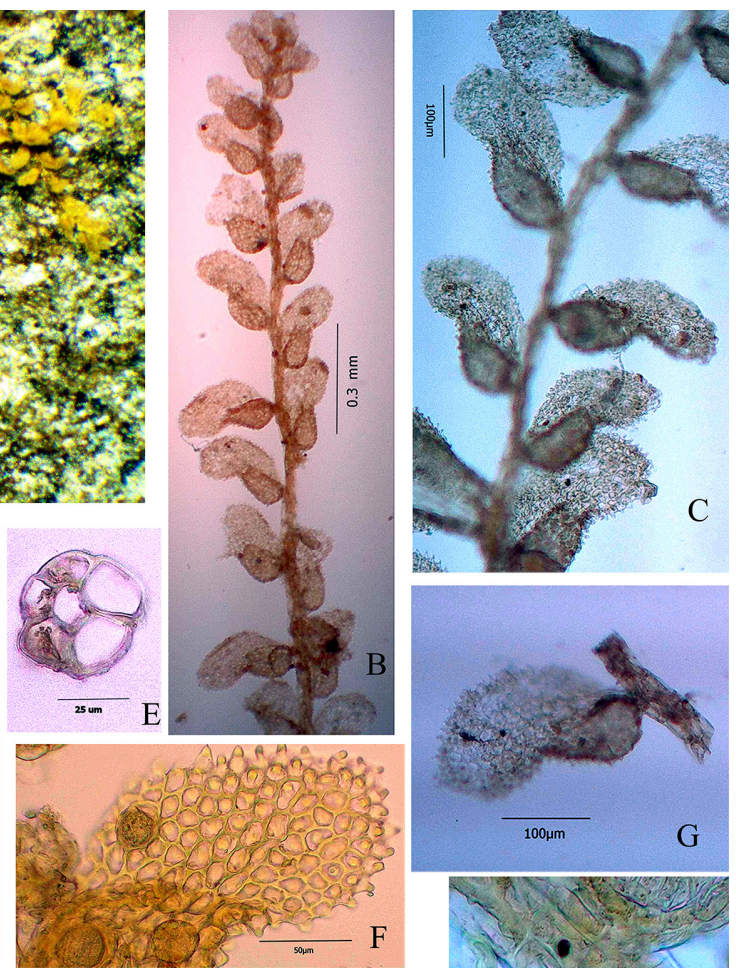

Fig. 2. Cololejeunea manilaliana. $\mathrm{A}=$ habit; $\mathrm{B}-\mathrm{C}=$ branch; $\mathrm{D}=$ branch with gynoecium; $\mathrm{E}=$ cross section of stem; F, J = leaf lobe; $\mathrm{G}=$ leaf lobe with lobule; $\mathrm{H}-\mathrm{I}=$ lobule; $\mathrm{K}$ = gemmae; $\mathrm{L}=$ rhizoids arising from stem 
Other specimens examined: INDIA, Kerala, Malappuram district, New Amarambalam Reserved Forest (1,250 m), coll.: Rajesh, K. P. (111812 a, 111820, 111825), 06.02.2010, (ZGC!).

Taxonomic notes: Cololejeunea manilalia sp. nov. shows similarities with C. indica Pande et R. N. Misra in plant size, irregular branching, presence of prominent spines, size of basal cells which is similar to vitta and lobule characters, especially bilobed nature with 2-celled first tooth and indistinct singlecelled second tooth, gynoecium on short lateral branches having one pair of bract. But the present species can be distinguished from $C$. indica Pande et R. N. Misra in its distantly arranged leaves, reniform shape of leaf, absence of stylus, size of cells in marginal and median portion, presence of nodular thickenings in median cells, absence of prominent vitta and number of cells in gemmae. C. manilalia sp. nov. is closely related to C. nilgiriensis G. Asthana et C. Srivast. in leaf arrangements and appearance of the plant, presence of spines on the leaves, absence of stylus, leaf incurved at middle, 20-celled gemmae and absence of vitta. But the present species differs from $C$. nilgiriensis G. Asthana et C. Srivast. in the size of the plant, reniform shaped leaf, irregular branching, size of the leaf cells, presence of intermediate nodular thickenings in median cells, bilobed lobule, first tooth long and straight usually 2-celled, small second tooth, ventral side spinose due to projecting cells. Present collection also related with C. spinosa (Horik.) Pande in size of plant, irregular branching, presence of prominent spines and one single dorsal papilla on each cell with bilobed lobule. C. manilalia sp. nov. differs from C. spinosa (Horik.) Pande by distantly arranged leaves, reniform shape and size of the leaf, absence of stylus, cell size, presence of nodular thickenings in median cells, absence of hyaline papilla on the inner surface of lobule at the first tooth and the gynoecium on short lateral branches.

Even though the present species shows similarities with $C$. indica Pande et R. N. Misra, C. nilgiriensis G. Asthana et C. Srivast. and C. spinosa (Horik.) Pande; it has its own characters such as arrangement of leaf on the stem, reniform shape of the leaf, absence of prominent vitta, absence of stylus and intermediate nodular thickenings in the median cells (Table 1).

Acknowledgements - The authors are thankful to Dr. Tamás Pócs, Botany Department, Eszterházy College, Hungary for commenting on the species. We are grateful to the staff members of the Kerala Forest Department at the New Amarambalam Reserved Forest for extending support during our field studies. Thanks are also due to the authorities of the Zamorin's Guruvayurappan College, Kozhikode for the facilities and support. One author (K. P. Rajesh) acknowledges the University Grants Commission (UGC) for financial assistance under Minor Research Project. We also acknowledge the financial support from the Science and Engineering Research Board of the Department of Science and Technology 
(DST-SERB), New Delhi and Kerala State Council for Science Technology \& Environment (KSCSTE), Thiruvananthapuram to the first (MCN) author.

\section{REFERENCES}

Asthana, G. and Srivastava, S. C. (2003): Indian Cololejeunea a taxonomic study. - Bryoph. Biblioth. 60: 1-155.

Day, M. and Singh, D. K. (2012): Epiphyllous liverworts of Eastern Hiamalayas. - Bishen Singh Mahendra Pal Singh, Dehra Dun, 415 pp.

Day, M., Singh, D. and Singh, D. K. (2010): Two more additions to Indian Cololejeunea (Hepaticae: Lejeuneaceae) from West Sikkim. - Indian J. Forestry 33: 615-618.

Jayakumar, R. (2005): Studies on the angiosperm flora and its diversity in the New Amarambalam Reserved Forests of Nilgiri Biosphre Reserve, Western Ghats of India. - PhD Thesis, Forest Research Institute University, Dehradun.

Jayakumar, R. and Nair, K. K. N. (2005): Flora of New Amarambalam Reserved Forests on the Western Ghats of India. - J. Econ. Tax. Bot. 29: 113-172.

Manju, C. N. and Rajesh, K. P. (2012): Symphysodontella madhusoodananii (Pterobryaceae, Moss) a new species from the Western Ghats of India. - PhytoKeys 18: 39-44. https://doi.org/10.3897/phytokeys.18.3314

Mizutani, M. (1961): A revision of Japanese Lejeuneaceae. - J. Hattori Bot. Lab. 24: 115-302.

Mizutani, M. (1986): Notes on the Lejeuneaceae. 11. Cololejeunea spinosa and its related species in Japan. - J. Hattori Bot. Lab. 60: 439-450.

Pócs, T. (1996): Epiphyllous liverworts diversity at the worldwide level and its threat and conservation. - Anal. Inst. Biol. Univ. Nac. Auton. Mexico, Ser. Bot. 67: 109-127.

Pócs, T., Bernecker, A. and Tixier, P. (2014): Synopsis and key to species of Neotropical Cololejeunea (Lejeuneaceae). - Acta Bot. Hung. 56: 185-226. https://doi.org/10.1556/ ABot.56.2014.1-2.14

Singh, A. P. and Nath, V. (2007): Hepaticae of Khasi and Jaintia Hills: Eastern Himalayas. Bishen Singh Mahendra Pal Singh, 382 pp.

Singh, S. K. and Pócs, T. (2016): Reinstatement of Cololejeunea indica Pande \& Misra, a name previously synonymous with C. spinosa (Horik.) Pande \& Misra. - Cryptogamie, Bryol. 37: 27-32. https://doi.org/10.7872/cryb/v37.iss1.2016.27

Sharma, J. K., Nair, K. K. N., Mathew, G., Ramachandran, K. K., Jayson, E. A., Mohanadas, K., Nandakumar, U. N. and Nair, P. V. (2002): Studies on the biodiversity of New Amarambalam Reserved Forests of Nilgiri Biosphere Reserve. - KFRI Research Report No. 247, Kerala Forest Research Institute, 240 pp. 